\title{
Superior mesenteric venous thrombosis: a retrospective study of thirteen cases
}

\author{
S. Muñoz, P. Cubo, J. González-Castillo, J. A. Nuevo, E.J. García-Lamberechts and A. Sanz \\ Service of Internal Medicine III. Hospital Clínico San Carlos. Madrid. Spain
}

\begin{abstract}
Objective: to analyze the epidemiology, associated risk factors, clinical presentation, diagnostic methods, treatment, and evolution of patients diagnosed with superior mesenteric venous thrombosis (SMVT) at an university hospital in Madrid.

Experimental design: retrospective and descriptive study. We review the medical records of patients with this diagnosis in our hospital from January 1998 to December 2002. Data were processed by using the SPSS vs. 11 software.

Patients: all thirteen subjects diagnosed with SMVT in that period were included.

Results: associated risk factors included tumoral conditions (5 patients), acute abdominal pathology (2), polyglobulia (1), prothrombin gene mutation (1), and anticardiolipin antibodies (1). No predisposing factor was found in 3 patients. Clinical presentation for all patients was abdominal pain, with nausea and vomiting being the second symptom in frequency (7). The diagnosis was reached by abdominal CT (9), arteriography (2), ultrasounds (1), and histology after intestinal resection (1). Treatment with only anticoagulation was initiated in 4 patients, whereas anticoagulation and surgery were performed in 5 cases. In 4 subjects no specific treatment was prescribed and only palliative measures were established due to a baseline end-stage condition. Five patients died, and four of them had a neoplasic condition as associated risk factor. Mortality in our series was 38.5\%.

Conclusions: SMVT is a very rare disease that is often associated with neoplasic pathology, which influences its high mortality. Due to non specific symptoms, imaging is essential for the diagnosis and the detection of associated risk factors. In our series, computed tomography imaging was the most profitable test.
\end{abstract}

Key words: Mesenteric venous thrombosis. Mesenteric ischemia. Intestinal infarction.

Recibido: $18-09-03$

Aceptado: 23-12-03

Correspondencia: Sonia Muñoz Albarrán. Servicio Medicina Interna III. Hospital Clínico San Carlos. C/ Dr. Martín Lagos, s/n. 28040 Madrid. Telf.: 9133038 02. e-mail: soniaalbarran@terra.es
Muñoz S, Cubo P, González-Castillo J, Nuevo JA, García-Lamberechts EJ, Sanz A. Superior mesenteric venous thrombosis: a retrospective study of thirteen cases. Rev Esp Enferm Dig 2003; 96: 385-394.

\section{INTRODUCTION}

Superior mesenteric venous thrombosis (SMVT) is a well known cause of intestinal ischemia or infarction. It is uncommon, but represents $5-15 \%$ of mesenteric ischemic events $(1,2)$, with mortality rates between 15 and $40 \%$ according to different series. It is influenced by its difficult and delayed diagnosis $(3,4)$. Originally, it was described by Elliot, in 1895 (5), but it was then characterized as an independent clinical entity by Warren and Eberhard, in 1935 (6).

Some risk factors predispose to SMVT: congenital and acquired prothrombotic states (hematological diseases, neoplasms, etc.), abdominal infectious and inflammatory diseases, abdominal postoperative states, hepatic cirrhosis and portal hypertension, and abdominal trauma (1,3,7-12).

Clinically, there is an acute form of presentation in which symptoms appear suddenly (minutes, hours) and is associated with a high risk of intestinal ischemia. In the subacute form of presentation, abdominal pain is present for days or weeks; intestinal ischemia is less frequent than in the acute forms, and bleeding from esophageal varices is rare. The limit between acute and subacute presentations is confusing; sometimes difficult to determine. Disproportionate abdominal pain in relation to physical examination findings, nausea, vomiting, anorexia and diarrhea are the most frequent symptoms. Hematemesis, hematochezia and melenas are less frequent. At last, there is a chronic form of presentation (months, years) whose symptoms are splenic or portal thrombosis-related, with bleeding from esophageal varices (1). 
Diagnosis is difficult and delayed, in most cases because of nonspecific symptoms and the absence of known predisposing risk factors. Sometimes a diagnosis is reached after laparotomy or autopsy.

It is important that an early diagnosis be reached, and that treatment be initiated as soon as possible to avoid complications and to reduce mortality. A high level of suspicion, a guided anamnesis for risk factors, an appropriated physical examination, and current imaging techniques (ultrasounds, computed tomography -CT-, arteriography) permit early diagnosis.

Once a diagnosis has been reached, anticoagulation therapy with systemic heparin is the basis of treatment. Surgery with subsequent anticoagulation is restricted only for cases with suggestive evidence of intestinal infarction.

In the present study we analyzed the epidemiological, clinical and diagnostic-therapeutic data of patients with a diagnosis of SMVT in our hospital. Until now, publications of case series with this pathology are rare. Results of different studies are similar in some points, but differ in others. We attempt to establish the current situation in our hospital and to compare our results with those of previous studies, when possible.

\section{PATIENTS, MATERIAL AND METHODS}

This study was performed in the "Hospital Clínico San Carlos", Madrid. This is a third-level hospital with a mean of 45,000 inpatients per year. Approximately 11,600 of them belong in Internal Medicine, Gastrointestinal and General Surgery departments. We included patients diagnosed with SMVT from January 1998 to December 2002 in these departments. Thirteen patients were obtained $(\mathrm{n}=13)$, seven males $(53.8 \%)$ and six females $(46.2 \%)$. Mean age was $68 \pm 12.53$ years, and ages varied from 52 to 83 years. We analyzed epidemiological data (age and sex), associated risk factors (coagulation abnormalities, immunological factors, presence of tumors, hematological diseases, abdominal infections or inflammatory conditions, postoperative states, presence of cirrhosis and portal hypertension), symptoms of clinical presentation, form of presentation (acute, subacute, chronic), laboratory results upon arrival in the emergency department (leukocytes, hemoglobin, hematocrit and venous gasometry), results of imaging techniques (plain abdominal radiography, ultrasonography, abdominal CT, arteriography), treatment of patients (anticoagulation, surgery or both) and evolution (outcome or decease).

The information was obtained from the anamnesis and supplementary exams on medical records of patients with SMVT.

When evaluating associated risk factors, we considered those that were present before patient admission to the hospital, and those that were diagnosed in the hospital or during patient follow-up at the outpatient clinic. Acute forms were considered those cases with a standing time shorter than 48 hours; chronic forms were those who had symptoms for more than one month. The remaining patients were considered to have subacute presentations.

We conducted a descriptive retrospective study. Due to the limited number of patients, a statistical signification study was not performed. Data were analyzed using the SPSS vs. 11 software.

\section{RESULTS}

Five patients $(38.5 \%)$ presented tumoral pathology, and three of them $(60 \%)$ had associated portal hypertension. Tumors had a pancreatic origin in three cases $(23.1 \%)$, one was originated from the thyroid gland $(7.7 \%)$ and, in the last case, multiple hepatic lesions were detected $(7.7 \%)$.

Two patients (15.4\%) developed SMVT following intraabdominal acute conditions; one case was due to diverticulitis, the other to the presence of a small bowel volvulus.

One patient had been diagnosed with polyglobulia (7.7\%). A prothrombin gene mutation was found during a coagulation study in another patient $(7.7 \%)$, and anticardiolipin antibodies were positive in a third one $(7.7 \%)$.

Three patients had no associated risk factors $(23 \%)$. One of them $(7.7 \%)$ was admitted to hospital again because of recurrent pulmonary embolism and deep venous thrombosis. Only one patient, this with positive anticardiolipin antibodies, had a history of deep vein thrombosis in another localization and recurrent pulmonary embo$\operatorname{lism}(7.7 \%)$.

In our series, three cases of SMVT were chronic $(23 \%)$, six were acute $(46.2 \%)$, and four were subacute forms $(30.8 \%)$. All cases developed abdominal pain $(100 \%)$, while nausea and vomiting were the second most frequent symptoms $(53.8 \%)$. Regarding laboratory results, in patients with chronic forms, we found no alterations in hemoglobin or hematocrit levels, and neither leukocytosis nor neutrophilia. On the contrary, patients with acute or subacute forms had leukocytosis and neutrophilia. A baseline arterial gasometry was performed in six patients $(46.2 \%)$, but only in one case $(16.7 \%)$ an evident metabolic acidosis was found; an intestinal infarction was demonstrated later. Gasometry was normal in two patients $(33.3 \%)$; one of them was treated surgically, and an intestinal infarction was detected. In the other patients, $\mathrm{HCO}_{3}^{-}$was in its lower normal range, with normal $\mathrm{pH}$.

Urgent plain abdominal radiographs were taken in eleven patients $(84.6 \%)$. Seven of them had pathologic findings $(63.6 \%)$. Most frequent findings included small bowel dilatation $(71.4 \%)$, air-fluid levels $(57.1 \%)$, colon dilatation $(28.6 \%)$, and colonic stop (28.6\%). Abdominal radiographs were normal in the remaining four cases $(36.4 \%)$.

Abdominal ultrasounds were performed in only seven cases $(53.8 \%)$, yielding clearly pathological results in six 
of them $(85.7 \%)$, and inconclusive findings in another patient $(14.3 \%)$. In two cases, ultrasounds demonstrated a tumor $(28.6 \%)$ (pancreatic tumor, multiple focal hepatic lesions), and SMVT associated with portal thrombosis in one case $(14.3 \%)$, and isolated portal thrombosis in another $(14.3 \%)$. Other relevant findings by the ultrasound study included small bowel and colonic wall enlargement, and the presence of fluid within the abdominal cavity.

An abdominal CT scan was performed in eleven patients $(84.6 \%)$. In nine of them, this study diagnosed SMVT $(81.8 \%)$, with associated portal thrombosis in four patients $(44.4 \%)$ and femoral vein thrombosis in two cases $(22.2 \%)$. In the other two patients (18.2\%), CT demonstrated colonic dilatation in one patient, and enlargement and dilatation of the small bowel in another patient, as well as free liquid within the peritoneal cavity. These are the most frequent findings. In two cases, CT showed related factors associated with SMVT that had not been diagnosed by ultrasounds (acute diverticulitis and a pancreatic neoplasm).

An arteriography was performed in three patients only $(23.1 \%)$. In one of them, the patient with acute diverticulitis, a colonic angiodisplasia was diagnosed (33.3\%). In the two remaining cases $(66.6 \%)$, arteriography demonstrated SMVT, which had not been diagnosed using the previous methods. In one patient, SMVT was associated with portal vein thrombosis and, in the latter case, with a cava vein thrombosis and vascularized pancreatic tumor.

In summary, among our thirteen patients with SMVT, one was diagnosed by ultrasounds $(7.7 \%)$; abdominal CT established the diagnosis in nine of them (69.2\%), and arteriography in two cases $(15.4 \%)$. Only in one case the diagnosis was obtained by histology after intestinal resection $(7.7 \%)$. The diagnostic yield of each of the previously mentioned diagnostic methods is displayed in figure 1.

In our series, six patients (46.2\%) presented an acute evolution, and four of them developed intestinal ischemia $(66.6 \%)$. In four cases symptoms were subacute, and three

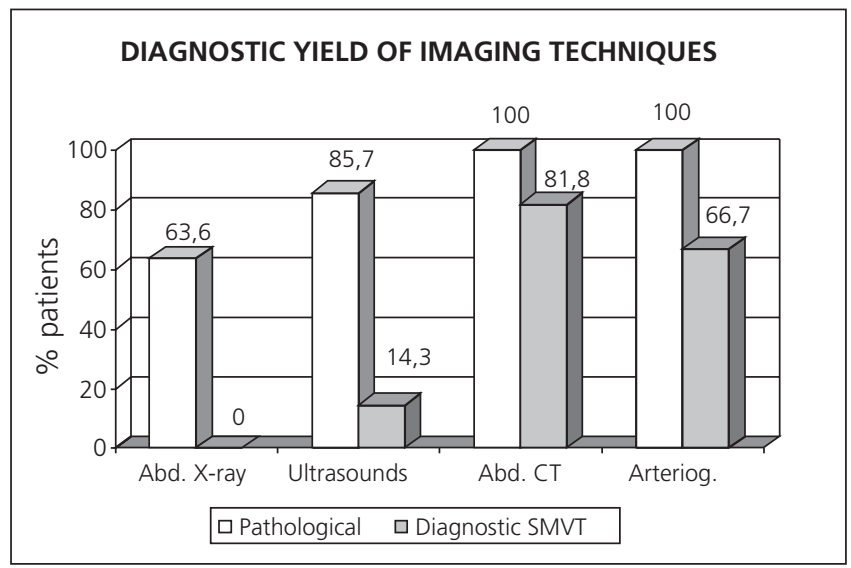

Fig. 1.- Percentage of pathologic and diagnostic SMVT results for each of the imaging techniques performed in our patients.

Se muestra, con respecto al total de pacientes en que se realizó cada prueba, el porcentaje en que se detectó algún hallazgo patológico y aquel en que la prueba fue diagnóstica de TVMS. of them suffered from intestinal ischemia (75\%). Amongst the seven patients with ischemic signs $(53.8 \%)$, surgical treatment was perfomed in only five cases $(71.4 \%)$; the remaining cases were not believed to be candidates for surgical management as they were considered palliative patients.

When treatment was reviewed, we found that four patients received anticoagulation therapy with sodium heparin as the only therapeutic measure $(30.8 \%)$; three of them were discharged after total recovery from our hospital $(75 \%)$, while one of them died $(25 \%)$. In the latter, a superficial intestinal infarction was demonstrated in the autopsy. Five patients received both anticoagulation and surgical treatment $(38.5 \%)$; all of them had a good clinical evolution and were discharged following recovery. In the last four patients no treatment was administered $(30.7 \%)$; three of them presented as chronic SMVT and one as an acute SMVT, but were considered palliative patients (three cases with pancreatic neoplasm and one case with multiple hepatic lesions) (Fig. 2).

Overall, five patients died $(38.5 \%)$ and eight were discharged after recovery $(61 \%)$ with oral anticoagulation or therapeutic doses of low molecular weight heparin (LMWH) as treatment.

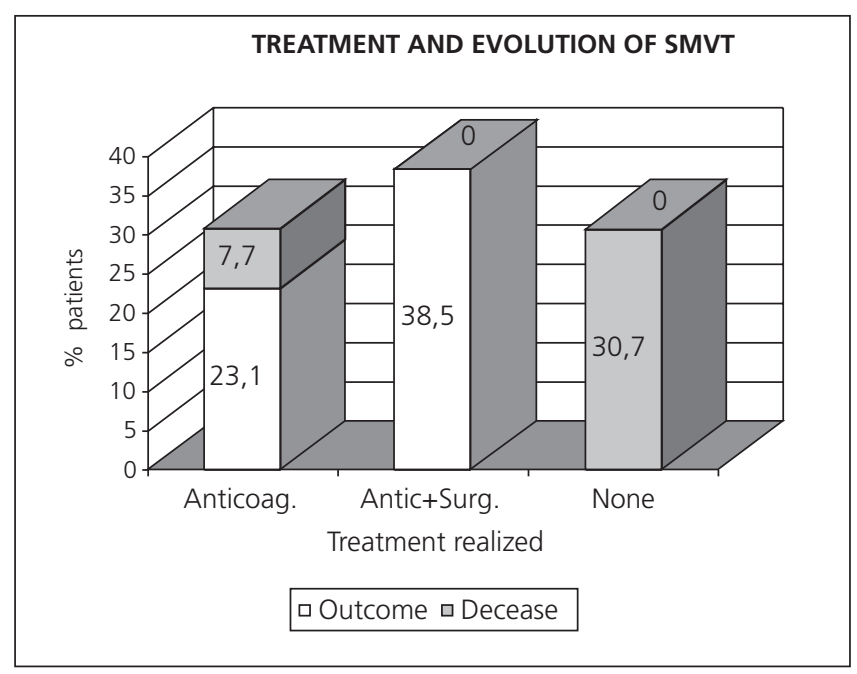

Fig. 2.- Percentage of outcomes and deaths on the total number of patients by treatment.

Se muestra el porcentaje de pacientes con respecto al total que fueron dados de alta o que fallecieron según el tratamiento realizado.

\section{DISCUSSION}

SMVT is a difficult-to-diagnose uncommon condition with a high mortality. Occasionally it is associated with thrombosis in other areas (portal, femoral veins,...). Clinical suspicion is essential for the diagnosis, which must be afterwards confirmed through image testing (radiography, ultrasonography, CT and arteriography in some cases). Early treatment is essential to reduce the high mortality of this condition. In our hospital we found only 
thirteen cases in the last five years, with a mortality rate of $38.5 \%$. This is similar to the mortality rate observed in series published by other authors $(3,4)$.

Risk factors associated with SMVT include: a) prothrombotic states: antithrombin III deficiency, protein C or protein $\mathrm{S}$ deficiency, presence of factor $\mathrm{V}$ Leiden or mutation in prothrombin gene, antiphospholipid antibodies, hyperhomocysteinemia, oral contraceptive use, pregnancy or neoplasm; b) hematological disorders: polycythemia vera, essential thrombocytosis, paroxysmal nocturnal hemoglobinuria; c) inflammatory diseases: pancreatitis, peritonitis and intraabdominal sepsis, inflammatory bowel disease or diverticulitis; d) postsurgical states: abdominal operations, splenectomy, sclerotherapy for esophageal varices; e) cirrhosis and portal hypertension; and f) other: blunt abdominal trauma (1). When none of these factors is detected, SMVT is referred to as idiopathic.

Neoplasms, oral contraceptive use, and hematological diseases, as well as pancreatitis, peritonitis and abdominal surgeries, are considered to be the most frequent factors associated with SMVT by some authors (1). According to other series, previous abdominal surgery (50\% of patients) and abdominal infections (appendicitis, cholecystitis, and inflammatory bowel disease, among others) followed by prothrombotic states $(28 \%)$ are the factors most frequently found involved in the etiology of SMVT (13). In other series prothrombotic states and hematological diseases are the most commonly found factors $(3,4,9,11,14)$. In our series, the risk factor that was present in a major number of cases was tumors $(38.5 \%)$, followed by acute intraabdominal conditions (15.4\%), prothrombotic states $(15.4 \%)$ and hematological disorders $(7.7 \%)$.

The number of idiopathic cases varies in different studies. It ranges between 21 (13) and 37 (3) or $66.7 \%$ (4). These rates are not comparable as diagnostic methods used in patients diagnosed with SMVT are not specified. None associated risk factor was detected in $23 \%$ of our patients. The number of cases with unknown etiology is decreasing due to advanced imaging methods.

Most of the cases in our series followed an acute or subacute course. In these cases the related etiology was diverse. However, it is important to emphasize that all cases with a chronic evolution were associated with splenic-portal axis tumors, and $66.7 \%$ of them had portal hypertension as well. Abdominal pain, nausea and vomiting are constant symptoms, which are present in acutesubacute and chronic forms. Bleeding from esophageal varices is a less frequent symptom even in chronic forms.

The presence of leukocytosis with neutrophilia, the increasing levels of hemoglobin and hematocrit, and the presence of metabolic acidosis when an intestinal infarction is established are laboratory changes that contribute to the diagnosis $(1,4)$. In our series there seems to exist some differences between acute-subacute and chronic forms. Leukocytosis and neutrophilia are present in all acute and subacute forms, while leukocytes remain within the normal range in chronic SMVT. We found no hemoconcentration in chronic forms, whereas it was present in only $50 \%$ of acute and subacute forms. In the only case with evident metabolic acidosis, an intestinal infarct was subsequently confirmed by gasometry. However, gasometry was normal in another patient in whom the presence of an intestinal infarct was later confirmed by laparotomy. In this way, data collected from abdominal exploration are of great value. The presence of peritoneal irritation signs should suggest the presence of an established intestinal infarct.

Once the suspected diagnosis is established by anamnesis, symptoms, physical examination and laboratory tests, imaging techniques must be performed. Plain abdominal radiographs are abnormal in 50-75\% of cases, according to different authors (1). We obtained a similar percentage in our series $(63.6 \%)$. When pathological, these techniques show indirect signs such as small bowel dilatation, air-fluid levels, wall edema, thumbprinting or partial obstruction of the small bowel $(1,3,4,14)$. It may be normal in $25-50 \%$ of cases. Abdominal ultrasounds provide indirect information, like enlargement of the bowel wall, presence of free liquid within the abdominal cavity, or presence of a thrombus in the superior mesenteric vein. At the same time it informs about possible causes of SMVT $(1,3,4)$. However, abdominal CT is by far the test of choice when SMVT is suspected, establishing the diagnosis in $90 \%$ of cases. However, it is less sensitive for the diagnosis of small-vessel thrombosis $(1,3,4,7,16)$. In our series, it was diagnostic in a minor percentage $(81.8 \%)$ of cases, though it was pathological in all patients in whom it was carried out. It shows a thrombus as a radiolucent area in the superior mesenteric vein, and contributes to detect possible causes of thrombosis. Other indirect information includes thickening of the bowel wall, pneumatosis intestinalis, gas in the portal vein, and presence of collateral circulation in cases with long standing time $(1,7,15,17,18)$.

Nuclear magnetic resonance has a high sensitivity and specificity for the diagnosis of SMVT as well; however, it does not offer any advantage over CT, except in patients with intolerance to intravenous contrasts due to hypersensitivity, or renal failure $(1,3,4)$. It was not performed in any of the patients in our series.

Mesenteric arteriography shows the thrombus and its associated vasospasm. A delay in the repletion of the superior mesenteric vein, prolonged opacification of the arterial arcades, or arterial reflux may all be observed. It is an invasive diagnostic method and for this reason it should be reserved for highly suspected cases when a diagnosis has not been reached by previous imaging methods or when small-vessel thrombosis is suspected (1). It helps differentiate between venous and arterial thrombosis, and provides also an access route for vasodilator administration (3). In our series, it was performed in only three cases; it confirmed the diagnosis in two patients and did not demonstrate the presence of thrombosis in the other one. Latter patient receiving intravenous sodium heparin during the last four days due to highly suspected SMVT according to abdominal CT. 
Sometimes diagnosis is obtained after intestinal resection. Only in one of our patients the diagnosis of SMVT was reached histologically after intestinal resection for infarction; it showed small-vessel thrombosis.

In our series, CT and arteriography were the most valuable tests for establishing an SMVT diagnosis. Due to the invasive character of arteriography, CT should be the selected procedure for all patients with suspected SMVT, because of its high sensitivity and smaller number of complications.

The treatment of acute or subacute SMVT consists of anticoagulation with or without surgery. Once a diagnosis has been established, treatment with intravenous heparin has to be initiated as soon as possible, maintaining APTT over two times its normal value. Even in patients with intestinal bleeding, treatment has to be initiated if the hemorrhagic risk is lower than that of an intestinal infarction (1). It has been demonstrated that treatment with heparin improves survival and decreases the risk of recurrence $(1,19,20)$. It also prevents thrombus propagation into the portomesenteric system $(4,19,21)$.

Anticoagulation with warfarin should only be initiated when there is no evidence of ischemic progression, and should be given for six to twelve months if there are no associated risk factors or when these have already disappeared. Otherwise, anticoagulation must be given for life (1).

Supporting measures like fluids, bowel rest and nasogastric suction play a fundamental role in treatment. However, the usefulness of intravenous antibiotics is not clearly established when intestinal infarction is absent (1).

Thrombolytic therapy may be another treatment option for patients whose diagnosis is well established, who are clinically stable, and have no evidence of intestinal infarction and no contraindication for this kind of therapy. So, this would be an effective treatment in a limited number of patients (22-24). A thrombectomy has been performed in some cases (25). Neither thrombolysis nor thrombectomy were performed in any of our patients.

Only patients with peritoneal signs on physical examination require an urgent surgical exploration. Surgery is the only effective treatment in cases with intestinal infarction. As soon as an intraoperative diagnosis of SMVT has been established, heparin perfusion must be initiated (1) because it decreases both mortality and recurrences (3). The aim of surgery is to preserve as much bowel as possible, only extirpating non-viable tissue. The aim of "second look" laparotomy, 24 hours after the first surgical procedure, is to avoid unnecessary resection of viable intestine. This is worthwhile in patients with extended intestinal ischemia in which venous irrigation is still present, though $(26,27)$.

In chronic presentations, treatment is symptomatic and is aimed at controlling esophageal varices bleeding or recurrent bleeding with pharmacological agents like propranolol, endoscopic therapy or portosystemic shunts (1).

In our series, SMVT presented a high rate of intestinal infarction. Excluding chronic forms, in which intestinal infarction is exceptional, $53.8 \%$ of patients developed ische- mia with intestinal infarction. In contrast with other authors (1), patients in our series with subacute SMVT developed more intestinal infarctions (75\%) than acute forms (66.6\%).

Patients treated only with anticoagulation had a mortality rate of $25 \%$ (one patient in each four), and intestinal infarction was demonstrated by autopsy. Patients treated with anticoagulation and surgery had a good outcome and all of them were discharged as cured (five of five). "Second-look" surgery was not performed in any case.

In our series mortality appeared to be related in most cases with the underlying condition causing SMVT, a tumor most often. Patients without a tumor had a good clinical outcome with a suitable treatment, even when intestinal infarction was present.

In conclusion, SMVT is an infrequent pathology with a high mortality rate. It should be considered in the differential diagnosis of patients with abdominal symptoms, particularly when risk factors are present. In many cases it is associated with a neoplastic condition or thrombosis in other areas (portal, femoral veins,...). Nonspecific symptoms (abdominal pain, nausea, vomiting) delay the diagnosis. A high suspicion rate, early diagnosis with the help of modern techniques (ultrasounds, abdominal CT, arteriography), and early treatment with heparin or surgery when needed all contribute to improved survival and the prevention of recurrence.

\section{REFERENCES}

1. Kumar S, Sarr MG, Kamath PS. Mesenteric venous thrombosis. N Engl J Med 2001; 345: 1683-8.

2. Grendell JH, Ockner RK. Mesenteric venous thrombosis. Gastroenterology 1982; 82: 358-72.

3. Choudhary AM, Grayer D, Nelson A, Roberts I. Mesenteric venous thrombosis. A diagnosis not to be missed! J Clin Gatroenterol 2000; 31: $179-82$.

4. Divino CM. In: Park S, Angel LP, Ellozy S, Spiegel R, Kim U. A retrospective study of diagnosis and manegement of mesenteric vein thrombosis. Am J Surgery 2001; 181: 20-3.

5. Elliot JW. The operative relief of gangrene of intestine due to occlusion of the mesenteric vessels. Ann Surg 1895; 21: 9-23.

6. Warren S, Eberhard TP. Mesenteric venous thrombosis. Surg Gynecol Obstet 1935; 61: 102-21.

7. Harward TRS, Green D, Bergan JJ, et al. Mesenteric venous thrombosis. J Vasc Surg 1989; 9: 328-33.

8. Boley SJ, Kaleya RN, Brandt LJ. Mesenteric venous thrombosis. Surg Clin North Am 1992; 72: 183-201.

9. Valla K. Venous Thrombosis in gastroenterology. J Mal Vasc 1991; 16: $243-8$.

10. Nair HT, Muscroft TJ. Idiopathic mesenteric venous thrombosis. Br J Clin Pract 1990; 44: 651-2.

11. Alving BM. The hipercoagulable states. Hosp Pract (Off Ed) 1993; 28: 109-21.

12. Slutzker DM, Pigula F. Small bowel infarction and death from primary mesenteric venous thrombosis. Am J Emerg Med 1987; 5: 126-9.

13. Warchauer DM, Lee JKT, Mauro MA, White GC II. Superior mesenteric vein thrombosis with radiologically occult cause: a retrospective study of 43 cases. AJR 2001; 177: 837-41.

14. Grendell JH, Ockner RK. Mesenteric venous thrombosis. Gastroenterology 1982; 82: 358-72.

15. Boley SJ, Kaleya RN, Brandt LJ. Mesenteric venous thrombosis. Surg Clin North Am 1992; 72: 183-201. 
16. Vogelzang RL, Gore RM, Anschuetz SL, Blei AT. Thrombosis of the splacnic veins: CT diagnosis. AJR Am J Roentgenol 1988; 150: 93-6.

17. Rosen A, Korobkin M, Silverman PM, et al. Mesenteric venous thrombosis: CT identification. AJR Am J Roentgenol 1984; 143: 83-6.

18. Matos C, Gansbeck V, Zalcman M, et al. Mesenteric venous thrombosis: early CT and US diagnosis and conservative management. Gastrointest Radiol 1986; 11: 322-5.

19. Abdu RA, Zakhour BJ, Dallis DJ. Mesenteric venous thrombosis1911 to 1984 . Surgery $1987 ; 101: 383-8$.

20. Matthews JE, White TP. Primary mesenteric venous occlusive disease. AM J Surgery 1972; 122: 579-83.

21. Chen M, Brown MC, Willson RA, et al. Mesenteric vein throm bosis. Four cases and review of the literature. Dig Dis 1996; 14 : 382-9.

22. Poplausky MR, Kaufman JA, Geller SC, Waltman AC. Mesenteric venous thrombosis treated with urokinase via the superior mesenteric artery. Gastroenterology 1996; 110: 1633-5.

23. Yankes JR, Uglieta JP, Grant J, Braun SD. Percutaneus transhepatic recanalization and thrombolysis of the superior mesenteric vein. AJR Am J Roentgenol 1991; 151: 289-90.

24. Rivitz SM, Geller SC, Hahn C, Waltman AC. Treatment of acute mesenteric venous thrombosis with transjugular intramesenteric urokinase infusion. J Vasc Interv Radiol 1995; 6: 219-28.

25. Bergentz S, Ericsson B, Hedner U, et al. Thrombosis in the superior mesenteric and portal veins: report a case treated with thrombectomy. Surgery $1974 ; 76: 286-90$.

26. Kodadadi J, Rozencwajg J, Nacasch N, Smidt B, Feuchtwanger MM. Mesenteric vein thrombosis: the importance of a second-look operation. Arch Surg 1980; 115: 315-7.

27. Levy PJ, Krausz MM, Manny J. The role of second-look procedure in improving survival time for patients with mesenteric venous thrombosis. Surg Gynecol Obstet 1990; 170: 287-91.

\title{
Trombosis de vena mesentérica superior: estudio retrospectivo de trece casos
}

\author{
S. Muñoz, P. Cubo, J. González-Castillo, J.A. Nuevo, E.J. García-Lamberechts y A. Sanz \\ Servicio de Medicina Interna III. Hospital Clínico San Carlos. Madrid
}

\section{RESUMEN}

Objetivo: analizar la epidemiología, factores de riesgo asociados, presentación clínica, métodos diagnósticos, tratamiento y evolución en pacientes diagnosticados de trombosis de vena mesentérica superior (TVMS) en un hospital universitario de Madrid.

Diseño experimental: estudio retrospectivo descriptivo. Se revisaron las historias clínicas de los pacientes ingresados en nuestro hospital entre enero de 1998 y diciembre de 2002 con este diagnóstico. Los datos fueron procesados mediante el programa informático SPSS vs. 11.

Pacientes: los trece pacientes diagnosticados de TVMS en ese periodo fueron incluidos.

Resultados: los factores de riesgo asociados fueron patología tumoral (5), patología aguda intraabdominal (2), poliglobulia (1), mutación del gen de la protrombina (1) y anticuerpos anticardiolipina (1). En 3 pacientes no se encontró factor predisponente. La presentación clínica de todos los pacientes fue dolor abdominal, siendo las náuseas y vómitos el segundo síntoma en frecuencia (7). El diagnóstico se obtuvo por TC abdominal (9), arteriografía (2), ecografía (1) y por histología tras resección intestinal (1). Se realizó anticoagulación aislada en 4 pacientes y anticoagulación más cirugía en 5 casos. En 4 no se realizó tratamiento específico por tratarse de pacientes paliativos debido a la patología de base. Cinco pacientes fallecieron, cuatro de ellos presentaban neoplasia como factor asociado. La mortalidad fue de 38,5\%.

Conclusiones: la TVMS es una entidad muy poco frecuente, asociada en muchos casos patología neoplásica, lo que influye en su elevada mortalidad. Por la inespecificidad de los síntomas las pruebas de imagen son esenciales para el diagnóstico y para detectar factores asociados. En nuestra serie el TC fue la prueba más rentable.

Palabras clave: Trombosis de vena mesentérica. Isquemia mesentérica. Infarto intestinal.

\section{INTRODUCCIÓN}

La trombosis de vena mesentérica superior (TVMS) es una causa reconocida de isquemia o infarto intestinal. Aunque poco frecuente, constituye el 5-15\% de los casos de isquemia mesentérica $(1,2)$ y presenta una tasa de mortalidad de $15-40 \%$ según las series, a lo que contribuyen la dificultad para el diagnóstico y la demora en el mismo (3,4). Descrita inicialmente por Elliot en 1895 (5), fue caracterizada como entidad clínica independiente, por Warren y Eberhard en 1935 (6).

Existen una serie de factores de riesgo que favorecen la aparición de TVMS. Estos son los estados de hipercoagulabilidad congénitos y adquiridos (enfermedades hematológicas, neoplasias,...), las infecciones y enfermedades inflamatorias abdominales, los estados postquirúrgicos, la cirrosis e hipertensión portal, y los traumatismos abdominales $(1,3,7-12)$. 
Clínicamente se distinguen una forma aguda en la que los síntomas aparecen bruscamente (minutos, horas) y que está asociada a elevado riesgo de isquemia intestinal. Una forma subaguda con dolor abdominal durante días e incluso semanas. En esta forma la isquemia intestinal es menos frecuente que en las formas agudas y el sangrado por varices esofágicas es raro. El límite entre las formas agudas y subagudas es confuso; a veces, difícil de precisar. Dolor abdominal desproporcionado a los hallazgos de la exploración física, náuseas, vómitos, anorexia, diarrea, son los síntomas más frecuentes. La hematemesis, hematoquecia o melenas se dan con menor frecuencia. Y por último, una forma crónica (meses, años) que se manifiesta como complicaciones de trombosis portal o esplénica en forma de sangrado por varices esofágicas (1).

El diagnóstico es difícil, por la inespecificidad de los síntomas y la ausencia de factores predisponentes conocidos en los pacientes, y se demora en la mayoría de los casos. En ocasiones se realiza el diagnóstico tras la laparotomía o la autopsia.

Es importante realizar un diagnóstico precoz e instaurar el tratamiento lo más pronto posible para evitar complicaciones y reducir la mortalidad. Un alto índice de sospecha, la historia clínica dirigida a detectar factores predisponentes y las modernas técnicas de imagen (ecografía, TC, arteriografía) permiten hacer un diagnóstico precoz.

Realizado el diagnóstico, la anticoagulación con heparina constituye el pilar básico del tratamiento. La cirugía queda reservada sólo para aquellos casos en que haya signos sugerentes de infarto intestinal, siempre seguida de anticoagulación.

En el presente estudio se analizan los datos epidemiológicos, clínicos y diagnóstico-terapéuticos de los pacientes diagnosticados de TVMS en nuestro hospital. Hasta el momento actual son escasas las publicaciones de series de casos con esta patología. Los resultados entre los distintos estudios son coincidentes en algunos aspectos, pero dispares en otros. Pretendemos conocer cuál es la situación en nuestro hospital, comparando nuestros resultados con los de estudios anteriores en la medida de lo posible.

\section{PACIENTES, MATERIAL Y MÉTODOS}

El estudio se realizó en el Hospital Clínico San Carlos de Madrid. Se trata de un hospital de tercer nivel con una media de unos 45.000 ingresos hospitalarios por año, de los cuales aproximadamente unos 11.600 se realizan en los servicios de Medicina Interna, Cirugía General y Aparato Digestivo. Se seleccionaron todos los pacientes diagnosticados de TVMS en los servicios de Medicina Interna, Digestivo y Cirugía General de nuestro hospital desde enero de 1998 a diciembre de 2002. Se obtuvieron un total de trece pacientes $(n=13)$, siete varones $(53,8 \%)$ y seis mujeres $(46,2 \%)$. La edad media fue de 68 años con desviación estándar de 12,53, edad máxima de 83 y mínima 52. Se analizaron los datos epidemiológicos (edad y sexo), factores de riesgo aso- ciados (alteraciones de la coagulación, alteraciones inmunológicas, presencia de neoplasia, enfermedades hematológicas, infecciones o procesos inflamatorios intraabdominales, estados postquirúrgicos, presencia de cirrosis e hipertensión portal), los síntomas de presentación clínica, el tiempo de evolución (aguda, subaguda, crónica), los parámetros analíticos a la llegada al servicio de urgencias (leucocitos, hemoglobina, hematocrito y gasometría venosa), los resultados de las pruebas de imagen (radiografía simple, ecografía abdominal, TC abdominal, arteriografía), el tratamiento realizado (anticoagulación, cirugía o ambas) y la evolución del paciente en el ingreso (alta o exitus).

Los datos se obtuvieron mediante revisión de las historias clínicas y de las pruebas complementarias de los pacientes con diagnóstico de TVMS.

En cuanto a los factores de riesgo asociados se tuvieron en cuenta tanto los que ya estaban presentes en el momento del ingreso como aquellos que se diagnosticaron durante el mismo o en el seguimiento posterior del paciente en consultas.

Se consideraron formas agudas aquellos casos con menos de 48 horas de evolución y formas crónicas aquellas con síntomas de más de 1 mes de evolución, siendo consideradas formas subagudas el resto.

Realizamos un estudio descriptivo retrospectivo. Dado el escaso número de pacientes encontrado no se ha realizado estudio de significación estadística. Los datos han sido procesados mediante el programa informático SPSS vs. 11.

\section{RESULTADOS}

Cinco pacientes $(38,5 \%)$ presentaban patología tumoral, de los cuales tres $(60 \%)$ tenían hipertensión portal asociada. Tres de las neoplasias eran de origen pancreático $(23,1 \%)$, una tiroidea $(7,7 \%)$ y en el otro caso se objetivaron LOES hepáticas $(7,7 \%)$.

En dos de los pacientes $(15,4 \%)$ la TVMS se asoció a procesos agudos intraabdominales, una diverticulitis y un vólvulo de intestino delgado en el otro caso.

Un paciente estaba diagnosticado de poliglobulia $(7,7 \%)$. En otro de los casos se encontró en el estudio de coagulación una alteración del gen de la protrombina $(7,7 \%)$, y en otro paciente los anticuerpos anticardiolipina fueron positivos $(7,7 \%)$.

En tres de los pacientes no había factor de riesgo claro asociado (23\%). Uno de ellos $(7,7 \%)$ reingresó posteriormente por TEP y TVP recidivantes. Sólo uno de los pacientes tenía antecedentes de trombosis venosa en otra localización y TEP previos $(7,7 \%)$, aquel con anticuerpos anticardiolipina positivos.

En nuestra serie tres casos eran TVMS de evolución crónica $(23 \%)$, seis eran formas agudas $(46,2 \%)$ y cuatro subagudas $(30,8 \%)$. El proceso se presentó en todos los casos con dolor abdominal (100\%) siendo las náuseas y los vómitos el segundo síntoma en frecuencia (53,8\%). Analíticamente, en las formas crónicas no se objetivaron 
alteraciones en los niveles de hemoglobina y hematocrito ni tampoco leucocitosis ni neutrofilia. Por el contrario, el resto de los casos, formas agudas y subagudas, presentaron leucocitosis con neutrofilia. Se realizó GAB a seis de los pacientes $(46,2 \%)$ y sólo en un caso apareció clara acidosis metabólica $(16,7 \%)$, demostrándose infarto intestinal posteriormente. En dos pacientes la GAB fue normal $(33,3 \%)$; uno de ellos fue intervenido quirúrgicamente detectándose infarto intestinal. En el resto de los casos el HCO3 estaba disminuido manteniéndose el pH dentro de la normalidad.

La radiografía simple de abdomen se realizó de urgencia en 11 pacientes $(84,6 \%)$. Fue patológica en 7 de ellos $(63,6 \%)$. Los hallazgos más frecuentes fueron asas de intestino delgado dilatadas $(71,4 \%)$, presencia de niveles hidroaéreos $(57,1 \%)$, dilatación del colon $(28,6 \%)$ y stop colónico $(28,6 \%)$. En los cuatro casos restantes $(36,4 \%)$ la radiografía fue normal.

La ecografía abdominal se realizó sólo en 7 pacientes $(53,8 \%)$, siendo claramente patológica en 6 de los casos $(85,7 \%)$ y mostrando hallazgos anodinos en el otro paciente $(14,3 \%)$. Objetivó patología tumoral en 2 casos $(28,6 \%)$ (tumor pancreático, LOES hepáticas) y mostró TVMS asociada a trombosis portal en un paciente $(14,3 \%)$ y trombosis portal aislada en el otro (14,3\%). Otros hallazgos relevantes, aportados por la ecografía lo constituyen el engrosamiento de la pared de asas intestinales y del colon y la presencia de líquido libre.

El TAC abdominal se realizó a 11 de los pacientes (84,6\%). En 9 de ellos fue diagnóstico de TVMS (81,8\%), asociada a trombosis portal en 4 pacientes $(44,4 \%)$ y además a trombosis de venas femorales en 2 casos $(22,2 \%)$. En los pacientes en que no fue diagnóstico de TVMS ( 2 casos, $18,2 \%$ ) mostró dilatación del colon en un paciente y engrosamiento con dilatación de asas de delgado en otro, y líquido libre, que constituyen los hallazgos más frecuentes. En 2 de los casos $(18,2 \%)$ contribuyó al diagnóstico de los factores relacionados con TVMS que no habían sido diagnosticados por ecografía (un caso de diverticulitis aguda y una neoplasia pancreática).

Sólo en 3 pacientes se realizó arteriografía $(23,1 \%)$. En un caso $(33,3 \%)$, el asociado a diverticulitis aguda, sólo mostró angiodisplasia de colon derecho. En los otros 2 casos $(66,6 \%)$ en los que la TVMS no había sido diagnosticada por otras pruebas, la TVMS apareció asociada a trombosis de la porta en 1 caso y a trombosis de vena cava y masa pancreática vascularizada en el otro.

Así pues, de los 13 pacientes, 1 fue diagnosticado por ecografía $(7,7 \%)$; en 9 de ellos la prueba diagnóstica fue el TC abdominal $(69,2 \%)$, y en 2 casos $(15,4 \%)$ la arteriografía. Tan sólo en un paciente el diagnóstico se obtuvo con la anatomía patológica tras la resección intestinal $(7,7 \%)$. La rentabilidad diagnóstica de cada una de las pruebas anteriormente descritas queda reflejada en la figura 1.

En nuestra serie 6 de los pacientes $(46,2 \%)$ presentaban cuadro de evolución aguda, de los que 4 presentaron isquemia intestinal $(66,6 \%)$. En 4 pacientes $(30,8 \%)$ los síntomas aparecieron de forma subaguda y, de ellos, tres (75\%) sufrieron isquemia intestinal. De los 7 pacientes con signos de isquemia $(53,8 \%)$, sólo se realizó cirugía en 5 casos $(71,4 \%)$. El resto no se intervinieron por considerarlos pacientes paliativos.

En cuanto al tratamiento, se realizó anticoagulación con heparina sódica, como único tratamiento en 4 pacientes $(30,8 \%) ; 3$ de ellos fueron dados de alta $(75 \%)$ y 1 falleció $(25 \%)$, demostrándose infarto intestinal superficial en la autopsia. En 5 casos se anticoaguló y se realizó intervención quirúrgica $(38,5 \%)$, con buena evolución clínica y alta hospitalaria. En los cuatro pacientes restantes no se realizó ningún tratamiento $(30,7 \%)$; 3 de ellos presentaban formas de evolución crónica y uno de ellos aguda, pero fueron considerados pacientes paliativos (3 pacientes con neoplasia pancreática y un paciente con LOES hepáticas) (Fig. 2).

Del total de pacientes 5 fallecieron $(38,5 \%)$ y 8 fueron dados de alta $(61,5 \%)$ con anticoagulación oral o con HBPM a dosis terapéuticas.

\section{DISCUSIÓN}

La TVMS es una entidad poco frecuente, de diagnóstico difícil y elevada mortalidad. En ocasiones se asocia a trombosis de otros territorios (porta, venas femorales,...). La sospecha clínica es fundamental para el diagnóstico, que se confirmará posteriormente con pruebas de imagen (radiografía, ecografía, TC y en algunos casos arteriografía). La rápida aplicación del tratamiento es esencial para reducir la elevada mortalidad que presenta este proceso. En nuestro hospital sólo hemos encontrado una incidencia de 13 casos en los últimos 5 años con una tasa de mortalidad del $38,5 \%$, similar a la observada en las series de otros autores $(3,4)$.

Los factores de riesgo asociados a TVMS son: a) los estados protrombóticos: déficit de antitrombina III, proteína C o proteína $\mathrm{S}$, presencia de factor $\mathrm{V}$ de Leiden o mutaciones del gen de la protrombina, anticuerpos antifosfolípido, hiperhomocisteinemia, uso de anticonceptivos orales, embarazo o neoplasias; b) enfermedades hematológicas: policitemia vera, trombocitosis esencial, hemoglobinuria paroxística nocturna; c) enfermedades inflamatorias: pancreatitis, peritonitis y sepsis de origen abdominal, enfermedad inflamatoria intestinal o diverticulitis; d) estados postquirúrgicos: cirugía abdominal, esplenectomía, escleroterapia de varices esofágicas; e) cirrosis e hipertensión portal; y f) otros: traumatismos abdominales (1). Cuando no se detecta ninguno de los anteriores factores se habla de TVMS idiopática.

Las neoplasias, la toma de anticonceptivos orales y las enfermedades hematológicas, así como las pancreatitis, peritonitis y cirugías abdominales, son considerados por algunos autores como los factores más frecuentemente asociados a TVMS (1). Según otras series, la cirugía pre- 
via abdominal (50\% de los pacientes) y las infecciones abdominales (apendicitis, colecistitis, enfermedad inflamatoria intestinal,...) seguidos de los estados protrombóti$\cos (28 \%)$ son los factores que con más frecuencia se encuentran (13). En otras series son los estados protrombóticos y las enfermedades hematológicas los factores más frecuentes $(3,4,9,11,14)$. En nuestra serie el factor de riesgo presente en un mayor número de casos fueron las neoplasias $(38,5 \%)$ seguido de los procesos agudos intraabdominales $(15,4 \%)$, los estados protrombóticos $(15,4 \%)$ y los procesos hematológicos $(7,7 \%)$.

Los casos de enfermedad idiopática varían según las series, oscilando entre 21 (13), 37 (3) y 66,7\% (4). Estas cifras son difícilmente comparables, dado que no se especifican los procedimientos diagnósticos que se llevaron a cabo con los pacientes una vez diagnosticados de TVMS. En el $23 \%$ de nuestros pacientes no se detectó factor de riesgo asociado. Con el avance de las pruebas diagnósticas el número de casos de etiología desconocida tiende a disminuir.

La mayoría de los casos de nuestra serie fueron de evolución aguda y subaguda. En estos casos la etiología relacionada es muy variable. Cabe destacar, sin embargo, que todos los casos de evolución crónica se asociaron a neoplasias del eje espleno-portal y el $66,7 \%$ de estos casos presentaban hipertensión portal asociada. El dolor abdominal, las náuseas y vómitos son síntomas constantes, presentes tanto en las formas agudas-subagudas como en las crónicas. El sangrado por varices incluso en las formas crónicas es un síntoma menos frecuente.

La presencia de leucocitosis con neutrofilia, el incremento de los niveles de hemoglobina y hematocrito y la presencia de acidosis metabólica cuando hay infarto intestinal establecido son parámetros analíticos que contribuyen al diagnóstico $(1,4)$. En nuestra serie parecen existir diferencias entre las formas agudas y subagudas, y las formas crónicas. La leucocitosis y neutrofilia están presentes en todas las formas agudas y subagudas, mientras que en las TVMS de evolución crónica los leucocitos permanecen dentro del rango normal. Tampoco se objetiva hemoconcentración en ninguna de las formas crónicas, estando presente sólo en el $50 \%$ de las formas agudas y subagudas. En el único caso en que apareció acidosis metabólica clara en la gasometría se confirmó posteriormente la presencia de infarto intestinal, pero en otro de los pacientes de nuestra serie la gasometría fue normal y se confirmó tras la laparotomía la presencia de infarto. En este sentido los datos que aporta la exploración abdominal tienen un gran valor. La presencia de signos de irritación peritoneal debe hacer pensar en la presencia de infarto intestinal.

Establecido el diagnóstico de sospecha por la anamnesis, la clínica, la exploración física y los hallazgos de laboratorio se procederá a la realización de pruebas de imagen. La radiografía simple de abdomen es patológica en un 50-75\% de los casos, según algunos autores (1). En nuestra serie hemos obtenido un porcentaje similar
$(63,6 \%)$. Cuando es patológica muestra signos indirectos como dilatación de asas de delgado, niveles hidroaéreos, edema de pared, imágenes en huella de dedo, obstrucción parcial de intestino delgado $(1,3,4,14)$. Puede ser normal, en un $25-50 \%$ de los casos. La ecografía abdominal proporciona datos indirectos como engrosamiento de las paredes del intestino, presencia de líquido libre intraabdominal y puede detectar la presencia de trombos en la vena mesentérica superior. A la vez informa de posibles causas de la TVMS $(1,3,4)$. Sin embargo el TC abdominal con contraste es la prueba de elección ante la sospecha de TVMS. Contribuye a establecer el diagnóstico en un $90 \%$ de los casos, siendo menos sensible para las trombosis de pequeño vaso $(1,3,4,7,16)$. En nuestra serie fue diagnóstico en un porcentaje algo menor (81,8\% de los casos), aunque patológico en todos los pacientes en los que se realizó. Visualiza el trombo como una zona radiolúcida en el interior de la vena y proporciona información de posibles causas en relación con la trombosis. Otros datos indirectos son el engrosamiento de las paredes del intestino, pneumatosis intestinal, gas en la vena porta, y la presencia de circulación colateral en aquellos casos de evolución más prolongada $(1,7,15,17,18)$.

La resonancia magnética nuclear tiene también una elevada sensibilidad y especificidad para el diagnóstico de TVMS, sin embargo no parece aportar ninguna ventaja sobre el TC, salvo en aquellos pacientes con intolerancia al contraste intravenoso por hipersensibilidad o insuficiencia renal $(1,3,4)$. En nuestra serie no se realizó en ningún paciente.

La arteriografía mesentérica pone de manifiesto el trombo y el vasoespasmo asociado. Puede observarse una demora en el relleno de la vena mesentérica superior o bien una opacificación de las arcadas vasculares, así como reflujo arterial. Al tratarse de una técnica invasiva debería reservarse para aquellos casos con alta sospecha en los que no se haya obtenido el diagnóstico con las pruebas anteriores o bien, cuando se sospeche trombosis de pequeño vaso (1). Permite diferenciar trombosis venosas de trombosis arteriales y permite el acceso para la administración de vasodilatadores (3). En nuestra serie se realizó en tres casos. Confirmó el diagnóstico en 2 de ellos y no objetivó trombosis en el otro. Se trataba de una paciente que estaba recibiendo tratamiento con heparina sódica intravenosa los últimos cuatro días por elevada sospecha diagnóstica de TVMS según imagen del TC abdominal.

En algunas ocasiones el diagnóstico se obtiene tras la resección intestinal. Tan sólo en un paciente de nuestra serie el diagnóstico de TVMS se hizo con la anatomía patológica tras la cirugía de resección intestinal por infarto, mostrando trombosis de pequeño vaso.

En nuestra serie el TC y la arteriografía constituyeron las pruebas de mayor valor para establecer el diagnóstico de TVMS. Dado el carácter invasivo de la segunda el TC debería ser la prueba de elección ante todo paciente con sospecha de TVMS, por su elevada sensibilidad y mínima frecuencia de aparición de complicaciones. 
El tratamiento de la TVMS aguda o subaguda consiste en anticoagulación combinada o no con cirugía. Una vez establecido el diagnóstico se debe iniciar cuanto antes tratamiento con heparina intravenosa manteniendo el APTT por encima de dos veces el valor normal. Incluso en pacientes con sangrado digestivo debe iniciarse el tratamiento si el riesgo de hemorragia es menor que el riesgo de infarto intestinal (1). Se ha demostrado que el tratamiento con heparina mejora la supervivencia y disminuye el riesgo de recurrencia $(1,19,20)$. Además previene la propagación del trombo por el sistema portomesentérico $(4,19,21)$.

La anticoagulación con warfarina debe iniciarse sólo ante la evidencia de no progresión de la isquemia y debe mantenerse durante seis meses a un año si no hay ningún factor de riesgo asociado o si este ha desaparecido. En caso contrario se mantendrá la anticoagulación de por vida (1).

Las medidas de soporte como la sueroterapia, el reposo digestivo, y la sonda de aspiración nasogástrica son parte fundamental del tratamiento. Sin embargo, la necesidad de antibióticos intravenosos no está bien establecida en ausencia de infarto intestinal (1).

La terapia trombolítica podría ser otra opción de tratamiento en aquellos pacientes en que el diagnóstico está firmemente establecido, se encuentran clínicamente estables y no hay evidencia de infarto intestinal ni contraindicación alguna para la utilización de esta terapia. Por tanto este podría ser un tratamiento efectivo en un limitado número de pacientes (22-24). La trombectomía también se ha realizado en algún caso (25). En ninguno de nuestros pacientes se realizó trombolisis o trombectomía.

Sólo en aquellos pacientes con signos de peritonitis en la exploración física requieren exploración quirúrgica urgente. En aquellos casos con infarto intestinal la cirugía es el único tratamiento efectivo. Tan pronto como se establezca el diagnóstico intraoperatorio de TVMS se iniciará perfusión con heparina (1), lo que disminuye la mortalidad y las recidivas (3). El objetivo de la cirugía es conservar el máximo intestino posible, extirpando sólo el tejido no viable. Se propone la realización de una laparotomía "second-look", veinticuatro horas después de la primera, con el objetivo de evitar la resección, en la pri- mera intervención, de intestino que podría ser viable. Esto resulta de especial utilidad en pacientes con gran parte del intestino isquémico pero que conservan algo de flujo venoso $(26,27)$.

En las formas de evolución crónica el tratamiento es sintomático, teniendo como objetivo controlar el sangrado por varices esofágicas o el sangrado recurrente con agentes farmacológicos como el propranolol, terapia endoscópica o shunts portosistémicos (1).

En nuestra serie la TVMS presenta una alta tasa de infarto intestinal. Excluidas las formas de evolución crónica, en las que el infarto es excepcional, el 53,8\% de los pacientes presentaron isquemia con infarto intestinal. En contra de lo que parecen indicar otros autores (1), en nuestros pacientes las formas de evolución subaguda presentaron mayor tasa de infarto $(75 \%)$ que las formas de evolución aguda $(66,6 \%)$.

De los pacientes tratados sólo con anticoagulación hubo un $25 \%$ de mortalidad (1 paciente de 4), demostrándose infarto intestinal en la autopsia. Aquellos pacientes en que se realizó cirugía y anticoagulación evolucionaron favorablemente y fueron dados de alta todos ellos (5 de 5). En ninguno de ellos se realizó cirugía "second-look".

En nuestra serie la mortalidad aparece relacionada en la mayoría de los casos con el proceso subyacente a la TVMS, con frecuencia neoplasias. Los pacientes sin neoplasias presentan buena evolución clínica con tratamiento adecuado, aún en presencia de infarto intestinal.

En conclusión, la TVMS es una patología poco frecuente con elevada mortalidad. Debe tenerse en cuenta en el diagnóstico diferencial de todo paciente con sintomatología abdominal, máxime si coexiste algún factor de riesgo asociado. En muchos casos se asocia a patología neoplásica y en ocasiones se asocia a trombosis de otros territorios (porta, venas femorales,...). La inespecificidad de los síntomas (dolor abdominal, náuseas, vómitos,...) hace que se demore el diagnóstico. Un alto índice de sospecha, el diagnóstico temprano con la ayuda de las modernas técnicas diagnósticas (ecografía, TC abdominal, arteriografía), y el tratamiento precoz con heparina y cirugía si fuera necesario, contribuyen a mejorar la supervivencia y evitar las recurrencias. 